\title{
DETEKSI HEMAGLUTININ PROTEIN PERMUKAAN STAPHYLOCOCCUS AUREUS DENGAN MENGGUNAKAN ERITROSIT RATTUS NOVERGICUS STRAIN WISTAR
}

\author{
Fredine E. S. Rares \\ Bagian Mikrobiologi Fakultas Kedokteran Universitas Sam Ratulangi Manado \\ Email: inerares@ymail.com
}

\begin{abstract}
Staphylococcus aureus is now acknowledged as being the most important bacterial pathogen of human beings and animals. S. aureus infections are of special concern due to their abilities to cause a number of devastating complications. Bacteria adhesion molecules and receptor molecules in host cells have a role on such bacterial pathogenicity because the early step of pathogens, in order to cause infection, is their adherence to the surface of the host cells by using adhesion molecules. In fact, an adhesion molecule is identical to haemagglutinin protein. The aim of this research was to detect hemagglutinin protein in the surface protein of S. aureus. The research method was explorative-experimental, and carried out in a laboratory. Isolation of the $S$. aureus' surface protein was conducted by using a detergent material, namely $n$-Octyl- $\beta$-D-Glucopyranoside (NOG), through a multistage isolation, and then was treated with Sodium Dodecyl Sulfate-Polyacrylamid Gel Electroforesis (SDS-PAGE). Erithrocytes of Rattus novergicus strain wistar were used to determine the haemagglutinin by using a haemagglutination test. The research result showed that the hemagglutinin protein of $S$. aureus could be determined by using the hemagglutination test and SDS-PAGE with a molecular weight of $22 \mathrm{kDa}$.
\end{abstract}

Key words: Staphylococcus aureus, haemagglutinin protein.

\begin{abstract}
Abstrak: Staphylococcus aureus saat ini dinyatakan sebagai bakteri patogen paling penting pada manusia dan hewan. Infeksi yang disebabkan olehnya memang mendapatkan perhatian khusus karena banyak mengakibatkan komplikasi fatal. Sehubungan dengan patogenesis bakteri tersebut, langkah awal patogen dalam menimbulkan penyakit adalah melakukan adhesi pada sel hospes melalui molekul adhesin. Molekul adhesin identik dengan protein hemaglutinin. Tujuan penelitian ini adalah mendeteksi protein hemaglutinin protein permukaan $S$. aureus. Metode penelitian yang digunakan adalah eksploratif-eksperimental di laboratorium. Isolasi protein permukaan $S$. aureus dilakukan dengan menggunakan bahan deterjen $n$-Octyl- $\beta$-D-Glucopyranoside (NOG) melalui isolasi bertahap dan dilakukan SDSPAGE. Untuk mendapatkan protein hemaglutinin $S$. aureus, dilakukan uji hemaglutinasi dengan menggunakan eritrosit Rattus novergicus strain wistar. Hasil penelitian memperlihatkan bahwa protein hemaglutinin $S$. aureus dapat ditentukan dengan uji hemaglutinasi dan SDS-PAGE dengan bobot molekul 22,38 kDa.
\end{abstract}

Kata kunci: Staphylococcus aureus, protein hemaglutinin. 